\title{
Union Renewal and Business Strategies Strategic Codetermination of Works Councils and the Campaign “Better Not Cheaper" of the German Metalworkers' Union
}

\author{
Thomas Haipeter ${ }^{1}$ \\ ${ }^{1}$ Institute for Work, Skills and Training, University of Duisburg-Essen, Germany \\ Correspondence: Thomas Haipeter, Institute for Work, Skills and Training, University of Duisburg-Essen, \\ Germany. E-mail: thomas.haipeter@uni-due.de
}

Received: November 28, 2012

Accepted: December 17, 2012

Online Published: January 25, 2013

doi:10.5539/ibr.v6n3p40

URL: http://dx.doi.org/10.5539/ibr.v6n3p40

\begin{abstract}
The trade union campaign "Better not cheaper" of the German metalworkers' union IG Metall is one of the most famous attempts of union revitalization in Germany and at the same time a new approach of unions to influence business strategies. Focusing on the activation of works councils, the aim of the campaign is to cope with the problem of disorganized decentralization of collective bargaining by developing concepts for a renewal of business strategies in the firms. The paper is based on a research project recently finished. In the project 16 case studies of plants which have been part of the campaign have been made and a survey among union locals was conducted. The paper analyzes the effects of the campaign on works councils' codetermination, on labor relations and on business strategies. The author concludes that the results of the campaign have been mixed up to now. On the one hand, the campaign has proven to be successful in activating the works councils to challenge management concepts, to enhance competencies and resources and, most important, to develop new forms of expert participation of employees. On the other hand, the scope of strategic codetermination and of the renewal of business concepts has been rather narrow, and membership effects for the union have been only sporadic and indirect. Therefore, the campaign should provide strategic competencies for the works councils more systematically, and the fight for new business strategies should go hand in hand with membership campaigns in the plants.
\end{abstract}

Keywords: union renewal, works councils, campaigning, strategic codetermination, high-road strategies, globalization, expert participation

\section{Introduction}

What are the prospects of unions and other actors of collective labour like works councils to preserve or regain organizational power in an environment of globalisation and financialization? What can unions do, and are there good practices already developed? And what do these practices mean for the business strategies of companies?

In the last 15 or 20 years answers to this question had a focus mainly on developments in the United States or in the UK that have been characterized by the notion of 'union organizing'. The reorientation of unions in terms of membership and collective bargaining strategies in these countries seemed to be so profound and promising that organizing has become a new core paradigm of a good union practice in dealing with problems of membership decline and in regaining influence in industrial relations systems. Organizing was largely identified with union revitalisation and was regarded as an instrument for the unions to win members and influence (Bronfenbrenner, Friedman, Hurd, Oswald, \& Seeber, 1998). However, an open debate has been and still is whether good practices of collective labour developed in one country can easily been transferred to another country with different actors and institutional features. Moreover, maybe other practices have developed in other countries that do not fit easily into the patterns defined paradigmatically as a good practice. Another open question largely neglected refers to the consequences of union strategies on business strategies. In the US-context, hostile reactions of employers seem to be frequent, and unions have good reasons to anticipate these reactions in their strategies. However, in countries with cooperative traditions of labour relations, employers' reactions are quite less clear and it may make sense for the unions to try to combine revitalization strategies with more cooperative approaches concerning employers. So the balance of revitalisation, conflict and cooperation can be of very different kind in different institutional settings. 
This article tries to analyse such an attempt to develop a good practice of revitalisation of collective labour by referring to the most prominent union campaign in the last years implemented in Germany, the campaign "Better not cheaper" by the German metalworkers' union. Being a revitalization campaign in its origin, the campaign at the same time has several characteristics which are rather singular compared to campaigns known from US unions. First, it is focused mainly on the works councils and their role in the labor relations of the firms. According to the campaign, works councils are to be activated to develop and negotiate alternative business strategies. Works councils are to be enabled to argue in business matters competently and strategically with their employers. The basic idea is that codetermination of works councils should deal not only with the social consequences of business strategies, but also with the business strategies themselves in order to safeguard employment and to prevent the employers from derogations of collective bargaining norms or the opting out of collective bargaining agreements. The activation of works councils both includes improved services developed by the union to support works councils in economic action and rank-and-file participation of employees in developing alternative strategies.

Second, the campaign deals with business strategies and tries to define an ideal of good business strategies which are confronted with bad business strategies. "Better" strategies in the sense of the campaign are high-road-concepts focussing on innovation and high-quality production. The activation of works councils should go hand in hand with an activation of the comparative institutional advantages the German coordinated market economy still can offer from the point of view of the union. These business strategies are to be developed by the works councils as alternatives in case employers favour strategies of relocation, outsourcing and cost-cutting. Negotiating business strategies is the cooperative core of the campaign. In doing this, conflict is not ruled out; however, it would be obviously impossible to change business strategies against the will of management. So dealing with business strategies means that works councils have to strive for a new consensus with the employers.

How effective is the campaign in revitalising the union? Does the union succeed in activating the works councils? And in how far business strategies are affected by that? These are the questions to be tackled in this paper. My analysis is based on an empirical project I have been conducting in recent years. It was financed by the Hans-Böckler-Foundation of the German Trade Union Federation. After reflecting literature debates and outlining the project's methodological approach, I will give a short overview of the campaign and its historical backgrounds before going into the details of the empirical findings.

\section{Union Revitalization, Works Councils and Business Strategies}

Like in many countries, also in Germany characterizations of current trends in industrial relations have become rather sceptical. Many of them are contributing to what might be called a swan song for the former dual system of German industrial relations composed of collective bargaining on the industry level and codetermination by works councils on the company level. There are good reasons to argue that the dual system is in a state of erosion (Hassel, 1998) or at least segmentation between union and non union sectors, accompanied by a simultaneous process of fragmentation of labour standards that has the potential to undermine the shrinking core of the industrial relations system through increasing wage competition (Bosch, Haipeter, Latniak, \& Lehndorff, 2007).

However, there are some voices that argue that German industrial relations went through a phase of revitalization in the course of the financial crises of 2009/2010 (Müller-Jentsch, 2010). And unions did indeed contribute to the development of economic stimulus packages by the government and therefore to political decision making. Moreover, collective agreements were negotiated that contained many instruments designed to help the companies to cope with the crisis, while works councils played an important role in the organization of short-time working and, more general, working-time reductions at plant level. Thus coordination at plant, industry and state level seems to be back on the agenda. At the same time, however, the long-term trends mentioned above are continued. This is why these voices have remained in the minority, and for good reasons.

Also the current debates on works councils display much ambivalence. Works councils play a crucial role in German industrial relations, because over the long term they have become the main institution of employee representation at plant level (Kotthoff, 1998). Works councils have developed strong relationships with unions, forming what Streeck (1979) called a "contradictory unity". Within this mutual relationship, unions have developed responsibility for training, consultancy and other forms of support for works councils (among them the support provided by the collective bargaining agreements they negotiate, on which the works councils can build at plant level). For their part, works councils have become responsible for organizing and monitoring the implementation of collective agreements and for the recruitment of union members at plant level. The last point led Schmidt and Trinczek (1999) to speak of a structural asymmetry in the relationship between works councils 
and unions in favour of works councils, since works councils can exist without unions more easily than unions without works councils. At the same time works councils stand in a close relationship to the companies and have an intermediary position towards them, given their obligation according to the Works Constitution Act (WCA) to keep labor peace in the companies and to take into account the economic interests of their firms. This is why many of them, albeit in different forms and intensity, have developed a cooperative stance towards the employers (Kotthoff, 1994).

There are at least two aspects of the current development of works councils that give rise to a certain ambivalence of interpretation. First, in the mid-1990s, the concept of co-management was developed to describe the growing demands and opportunities for works councils to co-determine the introduction of new forms of work organisation, such as teamwork (Müller-Jentsch, 1995). This definition of co-management was challenged by Kotthoff, who argued that it stemmed in fact from a growing recognition of economic constraints and involved works councils in organizing workforce downsizing (Kotthoff, 1994) rather than influencing the reorganization of work (Kotthoff, 1995). After the turn of the century, Kotthoff's defensive interpretation of co-determination became more accepted, culminating in the equalization of co-management and the negotiation of employment pacts at plant level (Rehder, 2003). Moreover, concession bargaining was regarded as a threat to the power of works councils because of the problems of legitimacy it created. Whereas Kotthoff (1998) in the 1990s assumed that works councils had a mandate from employees to negotiate concessions with management as a part of a long-term deal designed to safeguard jobs, Rehder (2006) has suggested that works councils might lose their "output legitimacy" as they negotiate successive employment pacts. Growing legitimacy problems, she argues, weaken works councils' organizational powers because of internal conflicts and problems in mobilizing workers in disputes with management.

A second, albeit less intensively discussed ambivalence of interpretation is the role of works councils in union revitalization. Works councils have been regarded as a cause of union conservatism in the development of revitalization strategies. Two reasons are often advanced to explain this (Baccaro, Hamann, \& Turner, 2003; Frege \& Kelly, 2004). The first is that, in the past, membership recruitment was organized mainly by works councils and therefore was not part of unions' core business. And even if unions were to try to implement some forms of organizing strategies along the lines developed by unions in the Anglo-Saxon countries, they would still have to deal with the works councils on the issue of membership recruitment. Second, as intermediary actors, it is argued, works councils favour a social partnership approach that impedes the development of organizing strategies based on a conflictual and confrontational stance towards management. The idea that works councils operate as co-managers, negotiating employment pacts with management, seems to fit perfectly with this line of argument.

However, as Behrens (2009) has shown, the relationship between unions and works councils is complex and difficult to capture with the analytical categories deployed in the Anglo-Saxon debate on revitalization. Behrens argues that the service model, which has been widely regarded as a conservative counterpart to organizing models, may very well contribute to union revitalization in the German context. Effective codetermination by works councils largely relies on the services the works councils are offered by the unions. Moreover, good services have proven to be rather important in enabling works councils to fulfil the task of membership recruitment. Conversely, works councils can be regarded as essential to union revitalization; without works councils' support, unions will neither become stronger players in mobilizing for collective bargaining nor be successful in recruiting new members, to mention just two possible dimensions of revitalization.

Furthermore, it might well be asked what social partnership really means in the German context. There are good reasons why social partnership should be defined broadly as reflecting a basic consensus about the institutions of collective bargaining and codetermination in which the social partners are willing to make compromises in conflicts and to agree a more or less symmetrical distribution of organizational power, thereby making departure from the consensus costly for either side (Kädtler, 2009; similar: Turner, 1998). Such an interpretation would leave the social actors ample room for strategic manoeuvre and would by no means exclude conflict-oriented strategies by the works councils also aimed at membership recruitment.

Finally, it is far from certain what it means for the works councils to act as an intermediary actor. Of course they are an intermediary institution in the sense that they have to take into account by law the economic situation of their company or plant when deciding on action. However, there is a second sense of intermediation which is problematic to generalize (as in Müller-Jentsch, 1985). Here, intermediation denotes the definition and aggregation of labour's interests and the selection of those interests that can be negotiated easily with the other side. This kind of intermediation can be called corporatist because works councils are expected to act as the custodians of private interests (Streeck \& Schmitter, 1984). However, the institutional framework within which 
works councils operate does not preclude the kind of strategies, based on rank-and-file participation, that have been adopted by unions in the English-speaking world and that have been discussed - albeit also critically (Hickey, Kuruvilla, \& Lakhani, 2010) - as important elements in union revitalisation. It is a matter of strategic choice for works councils whether to operate as corporate actors or to develop various forms of rank-and-file participation. There is little doubt that works councils' traditional strategies have been and still are corporatist in style (Kotthoff, 1994). However, this does not mean that no changes are possible or even under way.

Thus the relationship between works councils and union revitalization is far from being set in stone; moreover, the works councils can be regarded as one of the main problems the unions face in attempts at revitalization. It is no accident that they became the main focus of the famous "Better not Cheaper" campaign launched by the German metalworkers' union. As Turner (2008) has argued convincingly, two very different forms of union revitalisation can be observed in Germany, initiated by different unions and taking place in very different sectors of the German economy. One is the organizing campaigns launched by the service sector union Ver.di in a number of retail companies, while the other is the new strategy of collective bargaining and works council activation adopted by the metalworkers' union IG Metall. Works councils play a decisive role in both strategies, because they are the institution through which the unions gain entry to individual plants and establishments. Campaigns in the retail sector have sought to build institutions like works councils and collective bargaining agreements from scratch in an environment hostile to unions, whereas the initiatives in the metalworking industries were aimed at revitalising institutions in what remains of the coordinated core of the German industrial relations systems. Not surprisingly, these approaches differ markedly in terms of the instruments used by the unions. In the retail sector, the union has tried to organize campaigns designed to attract the attention of the public and build coalitions with other social movements. In the metalworking industry, on the other hand, the union's goal is to activate the works councils that already exist.

IG Metall's "Better not Cheaper" campaign, which was developed and launched in North-Rhine Westphalia, the biggest of the collective bargaining regions in the metalworking industry, is usually regarded as the most important development in union revitalisation in the heartlands of the "German export machine". Thus Turner states that the campaign, together with membership campaigns timed to coincide with plant- level disputes on collective bargaining norms, offers an "unexpected promise for institutional revitalization" of industrial relations in Germany (Turner, 2008). What stands out is an empirical test of the high hopes that have been expressed about the "Better not Cheaper" campaign. Has the campaign really helped to activate works councils in situations in which they are on the defensive in the face of relocation threats and employment pacts? In how far have they proven to be able to negotiate new business strategies? And finally, is the activation of works councils contributing to the revitalisation of the union in the industry?

\section{Methods}

The analysis of the "Better not Cheaper" campaign is based on three methodological pillars. The first one is a survey among IG Metall's local union offices (Verwaltungsstellen) in North-Rhine Westphalia. In the survey, the heads of the offices were asked about the spread of the campaign among the plants for which they are responsible, about the background to the "better" practices adopted in the plants, about the topics that have been dealt with in the course of the "better" strategies and about the interactions between works councils and the union administration. Of the 43 local union offices in North Rhine-Westphalia, 19 responded, giving a return rate of about $44 \%$. It is difficult to say whether the other offices did not respond because they simply ignored our request to fill in the questionnaire, because there were no examples of practical applications of the campaign in these offices or because they were not sympathetic to the campaign (which is possible because the units are rather autonomous in the way they support and coordinate works councils). However, the fact that some of our case studies were located in union offices that did not respond to our survey makes the first interpretation more likely, i.e. we did not get a response because the heads of the offices did not have time to deal with the questionnaire. However, the other possibilities cannot be completely excluded.

The second methodological pillar of the study is case study analysis. We carried out case studies in a total of 16 different plants. The main criterion governing the selection of our case study sample was the information provided by the union and approved by the works councils that the works councils had developed new strategies that could be defined as "better" strategies in the sense of the campaign. By focusing on these cases, we were trying to ascertain what patterns of codetermination emerge alongside "better" practices and what conditions have to be met before works councils are able to develop these patterns.

Other selection criteria were to include plants of different size and of different ownership structures in order to be able to analyse the influence of these structural factors on codetermination practices. Consequently, our sample includes a broad range of industries, plant sizes and ownership structures (Table 1); the individual cases 
have been anonymised, with reference being made only to the main products produced. It has been surprising to observe that the influence of these factors has been marginal at best. No systematic differences could be found between works councils in plants of different sizes or ownership structure. The reason is that management strategy appears to be rather similar in all cases, driven by the globalization of production and the financialization of decision-making on products, investments or employment. I will return to this point later. Our sample did not include any of the large OEM plants in the automotive industry. It can be assumed that they would have made a difference, since the automotive works councils are usually regarded as the vanguard of the works council movement, being better endowed in material, intellectual and strategic resources than other works councils (Bergmann, 2001). Moreover, they have long experience of dealing with globalized company structures and internal competition between production sites (Haipeter, 2006). Some of the experts we interviewed referred explicitly to the automotive works councils as models for the kind of activation that was intended in the "Better not Cheaper" campaign.

Table 1. Case study sample

\begin{tabular}{|c|c|c|c|}
\hline & Industry & $\begin{array}{l}\text { Number of employees at site } \\
\text { (company if different) }\end{array}$ & Ownership structure \\
\hline Power train & Mechanical engineering (power transmission) & $400(690)$ & Hedge fund \\
\hline Miner & Mechanical engineering (mining) & $70(1,100)$ & Corporation \\
\hline Sealer & Automotive supplier (Sealing) & $340(43,000)$ & Corporation \\
\hline Electronics & Electronic industry (household appliances) & $1,800(10,000)$ & Family-owned \\
\hline Energy & Plant construction & $600(30,000)$ & Corporation \\
\hline Gear & Mechanical engineering (power transmission) & $2,400(6,700)$ & Corporation \\
\hline Cooler & Automotive supplier (radiator grills) & $200(700)$ & Management buyout \\
\hline Shiner & Lights/medical technology & $1,300(4,700)$ & Headquarters of limited company \\
\hline Motor & Automotive supplier (engines) & $2,600(5,000)$ & Corporation \\
\hline Truck & Automotive supplier (Interior) & 100 & Hedge fund \\
\hline Plough & Mechanical engineering (agricultural machinery) & 750 & Family-owned \\
\hline Switcher & Switcher & 450 (Site 1), 200 (Site 2) & Corporation \\
\hline Closer & Automotive supplier (Latches) & 1,100 & Hedge fund \\
\hline Steel & Cold rolling & 190 & Corporation \\
\hline Cement & Plant construction & 300 & Hedge fund \\
\hline Supplier & Automotive supplier (lights and electronics) & $\begin{array}{l}5,000 \text { (Site 1), 1,000 (Site 2) } \\
(10,000)\end{array}$ & Family-owned \\
\hline
\end{tabular}

The case studies consist of interviews with the chairmen of the works councils, the union's plant coordinators, other works councillors and, in some cases, HR managers, shop stewards and consultants commissioned by the works councils in the course of the "better" processes. Originally it was intended to carry out four intensive and 12 short case studies based only on interviews with one works council and one coordinator; in the course of the research, however, it became clear it would be useful to add other interviews, such as those with consultants, even in some of the short case studies (Table 2).

Table 2. Case study interviews

\begin{tabular}{|c|c|c|c|c|c|c|}
\hline & Works council chairman & Union coordinator & Other works councils & Management & Shop stewards & Consultants \\
\hline Power Train & 1 & 1 & 3 & 1 & 3 & \\
\hline Miner & 1 & 1 & & & & \\
\hline Sealer & 1 & 1 & 1 & & & 1 \\
\hline Electronics & 1 & 1 & & & & \\
\hline Energy & 1 & 1 & 1 & & & 1 \\
\hline Gear & 1 & 2 & & & & \\
\hline Cooler & 1 & 1 & 1 & 2 & & \\
\hline Shiner & 1 & 1 & & & 4 & 1 \\
\hline Motor & 1 & 1 & 1 & & & \\
\hline Truck & 1 & 1 & 1 & 1 & & \\
\hline Plow & 1 & 1 & & & 4 & \\
\hline Switcher & 1 & 1 & & & & 1 \\
\hline Closer & 1 & 1 & & & & \\
\hline Steel & 1 & 1 & 1 & & & \\
\hline Cement & 1 & 1 & 1 & & & \\
\hline Supplier & 1 & 1 & & & & \\
\hline
\end{tabular}


Finally, in addition to the survey and the case studies, we conducted a number of non-standardized interviews with experts from all levels of the union administration. We spoke with the vice-chairman of IG Metall, Detlef Wetzel, who developed and implemented the campaign in North-Rhine Westphalia between 2004 and 2008 when he was the union's chairman of the collective bargaining region, with a union expert organizing the campaign for union headquarters, with several experts from the North-Rhine Westphalia region who are coordinating and supporting the campaign today, with union-oriented business consultants and with members of IG Metall's further training institutions.

\section{The Background: Disorganization of Collective Bargaining in the Metalworking Industry}

The fact that institutions of labor relations still exist in the manufacturing sector does not mean that the needs for union revitalization are less severe than in the service sector. On the contrary, globalization and growing imbalances of power in favour of employers have hollowed out the institutions of industrial relations to a large degree. Although the institutional features of the "coordinated market economy" (Hall \& Soskice, 2001), such as collective agreements and codetermination, have proved to be rather stable, the substance of negotiations has changed (Dörre \& Brinkmann, 2005). Employers nowadays can demand concessions and unions and works councils can hardly avoid negotiating them.

The problems became more serious for IG Metall in the first years of the new century, accompanied by a massive campaign the employers and their associations, headed by the umbrella organization of the industry, Gesamtmetall, were launching, stressing the problems of Germany as a high-cost location and, from 2004 onwards, demanding increased working time without pay compensation. Germany was titled world champion of leisure time, and the union was accused of wanting to make labour regulation too inflexible. In their view, therefore, individual plants should be given the possibility of derogating from collective agreements.

However, derogations from collective agreements, both formal and informal, were already a more or less common practice at that time; and this was the by far the biggest problem the union was facing (See Haipeter, 2011a). Derogations allow employers to downgrade collectively agreed norms on wages and/or working times. They are usually accompanied by some counter-concessions offered by the employers, such as a temporary safeguarding of jobs and/or promises of investment (For a classification of derogations see Lehndorff \& Haipeter, 2011). At that time, the union had no control over the content of these formal and informal derogations or over the number of agreements concluded (Haipeter, 2009). Times changed when the employers' associations and the government forced IG Metall in 2003 and 2004 to negotiate a standardized and more extended derogation clause to be included in the collective agreements. This was duly achieved with the 2004 Pforzheim Agreement, which legalised derogations if they safeguarded jobs and increased the competitiveness of plants and companies. This agreement was supported by union modernisers in the hope that it would strengthen the union's control over derogations. For the time being, however, the reality was rather different. Instead of gaining control, the union found itself increasingly on the defensive, attacked by more and more companies demanding working time extensions and wage concessions. The Pforzheim Agreement seems to have aggravated the situation. Constructed as an instrument of organized decentralization (Traxler, 1995), the Pforzheim Agreement turned into a gateway for the disorganization (Doellgast \& Greer, 2007) of collective bargaining.

However, the crisis also increased the pressure within the union to find new solutions for the problems of disorganized decentralization. The fact that the crisis of collective bargaining had become evident - and could no longer be ignored as it had been before the Pforzheim Agreement - made it easier for the modernizers' camp at headquarters and in the regions to develop and put into practice new solutions that would otherwise have been rejected by powerful actors within the union. In the crisis situation, the positive returns from routines that had been remarkably successful in the past seemed to have disappeared; consequently, building on these routines no longer seemed to be a promising strategy.

In retrospect, it is clear that IG Metall developed two new strategies to cope with the crisis of disorganized decentralization. The first one was the implementation of new processes for dealing with derogations from collective agreements. They included new requirements for information flows between the union's different organizational levels, the inclusion of local and/or regional union officials in negotiations with management and rank-and-file participation in plant level negotiations. The effects of the new processes have been analyzed elsewhere (Haipeter, 2011b). In brief, it can be said that by redefining responsibilities and increasing the transparency of plant-level negotiations, IG Metall was able to coordinate and to re-organize decentralization in a rather effective way, which was surprising given the severity of the problems.

The second strategy for dealing with the crisis of disorganization was the activation of works councils in order to develop alternative concepts to downsizing, outsourcing or relocation. The origins of the strategy lay in the 
"Better not Cheaper" campaign that IG Metall started at the end of 2004 in North-Rhine Westphalia. Although the campaign was initially regional in character, it has developed into a national campaign supported by union headquarters. When the former head of the district, Detlef Wetzel, became vice-chairman of the union in 2008, resources were redistributed at IG Metall's headquarters and a new department of work and innovation was created to take responsibility for the activation of works councils with a view to enabling them to deal with economic and innovation issues. To date, the department has focused on three main areas of activity: coordination of a "crisis intervention" task force that organizes consultancy for works councils in plants in crisis; the development of an instrument for works councils to assess their plants' economic situation; and, finally, the development of plans to cope with the new lean production systems that are currently being implemented in many companies throughout the metalworking sector. Although the expansion of the campaign to national level is beyond the scope of this paper, it can be assumed that the types of action initiated or supported by the national campaign are rather similar to those associated with the regional campaign analyzed here.

\section{The "Better Not Cheaper" Campaign}

To speak about a well-planned campaign from the beginning would be to ignore the facts, for the campaign in its first phase was little more than a slogan that was easy to remember, open to different interpretations and effective in political discourse as a counter-argument against the employers' cost-cutting rhetoric. The idea was as simple as it was convincing: employers have to be able to compete successfully, but in order to do so they have to think about more than just cutting costs. What the union was suggesting was that employers should make use of employees' expertise and of companies' long-term innovative potential and actively promote both new forms of production that make full use of workers' skills and new and innovative products of high quality. All these aspects had already been highlighted in Hall and Soskice's analysis of the comparative institutional advantages of the German coordinated market economy (Hall \& Soskice, 2001). In challenging the strategic prerogatives of management, the "Better not Cheaper" campaign is regarded by its creators as a "maximum union demand in capitalism", as Detlef Wetzel characterized it in an interview. And this is why it soon became clear that the central target of the campaign was to be the works councils which, in the German institutional framework, are the only actors that are at least potentially able to play such a role in the plants.

This was a rather ambitious programme for works councils. Although their legal status is ensured by the WCA, the legislation does not explicitly enable them to engage in negotiations on strategic decisions regarding work and company organization, products or markets. Clause 92a, which was incorporated into the Act in the course of the WCA reform of 2001, allows works councils to make proposals to safeguard jobs and obliges management to consult with the works councils about the proposals. However, management is at liberty to reject the works councils' proposals with impunity, since the works councils have no means at their disposal of applying sanctions. One of the campaign messages was that works councils should become more active than the WCA requires and allows them to be. To be more precise, they were to become strategic by influencing management decisions rather than simply dealing with the aftermath of such decisions. And for the bulk of works councils in plants - apart from works councils in the large automotive companies mentioned above -, strategic codetermination posed a real challenge which required support from outside, because otherwise the campaign would have failed in those plants where it was most needed.

Thus, it soon became clear that the campaign would have to rely on a material infrastructure if it was to produce real effects in the plants. This infrastructure was developed in the form of projects financed largely by the regional and federal governments. In these projects, some of which have already finished while others are still running, several initiatives and instruments were developed by the union and the other members in the "Better not Cheaper" project team, which was (and still is) composed of union officials and external members, including consultants and academics.

The activities included numerous workshops for works councils dealing with topics chosen by the works councils, such as globalization, outsourcing or new production systems; industry reports analysing developments in sub-sectors such as the machine tool or agricultural machinery industries were produced; individual cases were investigated by the union, by union- oriented consultants and by academics; a network of union-oriented consultants was created; and industry networks of works councils and mutual support of works councils by works councils were promoted. Another important point was the identification of good practice examples right from the start of the campaign. The examples were presented at workshops by the works councils in question and on the campaign's Internet pages. They had the key function of showing how works councils" "Better not Cheaper" practices could work and how they were already working in some plants. It seems not too far-fetched to say that the time was right for just such a campaign: it was both a response on the manifold challenges confronting IG Metall and a continuation of strategies that had already been implemented in some plants, where 
works councils had been able to develop approaches similar to that adopted in the campaign. These works councils had been regarded by IG Metall as "beacons" guiding other works councils willing to go down a similar route. Two of these "beacons" were cases in our sample, whereas the other cases were inspired by the campaign in one way or another.

\section{The Spread of the Campaign in the Plants}

To get reliable information about the spread and practice of codetermination, we asked the local union offices in our survey how many works councils - not single works councils, but committees in plants - had developed a codetermination practice linked to the "Better not Cheaper" campaign in their offices. Of the 43 local union offices in North-Rhine Westphalia, 19 responded. Taken together, in these 19 offices "Better not Cheaper" played a role in 137 plants. Compared to the plants that are members of the employers' associations and therefore covered by collective bargaining agreements in the district of North-Rhine Westphalia, the number of "Better not Cheaper" cases in the 19 union offices represented about $10 \%$ of all the works council committees in the North-Rhine Westphalia district. If these figures are projected for all the administrative units in North-Rhine Westphalia, they would suggest that some $20 \%$ of plants belonging to the employers' associations were involved in the campaign. However, for the reasons given above this figure cannot be taken for granted because of the bias that may result from differences in the union offices' strategic approaches and ignorance of our survey on the part of officials.

The "Better not Cheaper" strategies emerged out of situations in which the union and works councils were on the defensive, which tends to confirm the pessimistic redefinition of co-management cited above: derogations ( $40 \%$ of cases), local alliances for jobs (19\%), threats to close plants or dismiss employees (27\%) and rationalization $(12 \%)$ were the motives indicated by union officials. The main objectives being pursued by the union and the works councils were prevention of off-shoring or outsourcing, increased investment and stronger codetermination and rank-and-file participation (Figure 1).
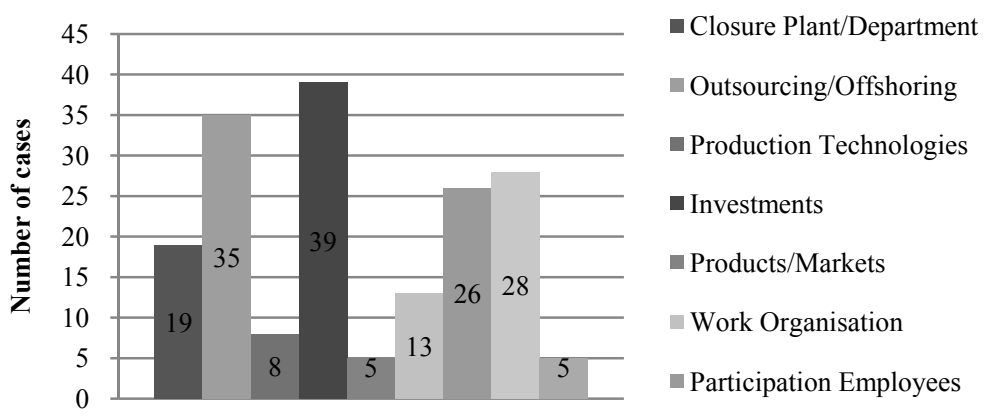

Figure 1. Negotiation objectives of works councils/unions

\section{7. "Better Not Cheaper" - a Strategic Approach to Codetermination}

What does it mean for codetermination when works councils act in line with the "Better not Cheaper" campaign? What does the campaign look like in practice? I will try to tackle these questions based on the case study analysis introduced above. Table 3 gives an initial overview of the results of the case study. In the rows of the table are listed the central issues in the cases, which will be explained and analyzed in the following sections. The "problem/motive" column lists the reasons given by the works councils to explain why they were forced to develop a new strategic approach to codetermination. "Works council strategy" denotes the ways works councils reacted, either by challenging management's business plans or plans of restructuring and reorganization, developing concepts of their own and/or by promoting and controlling the implementation of new plans. The "resources" column lists the resources works councils were able to use in developing new strategies, such as reorganizing the work in the committees, further training or advice provided union-oriented consultants. "Mode of interaction" denotes the ways plans are negotiated with management. I identify two types of strategy, which I describe as "dancing" and "boxing" strategies. These epithets will be explained below. "Employee participation" describes the ways employees participated in the development of new plans. Finally, the "organizational effects union" row provides an overview of the recruitment effects for the union that are attributed to the works councils' new practices. I put the term derogation in brackets in those cases, where recruitment effects took place but where the works councils attributed them to the fight against cost-reduction strategies in the course of 
disputes about derogations; in some cases, the fight against such strategies went hand in hand with the fight for new business plans, while in other cases it was an unrelated episode. However, the central difference between them is that in the case of derogations recruitment is regarded as an effect of rank-and-file participation in the form of membership voting in disputes, for example, whereas in the other case recruitment is interpreted as an effect of employees' participation as experts in the development of new organization and business plans. I will come back to this differentiation later on.

Table 3. Results of the case study analysis

\begin{tabular}{|c|c|c|c|c|c|c|}
\hline & $\begin{array}{l}\text { Problem } \\
\text { /motive }\end{array}$ & $\begin{array}{l}\text { Works council } \\
\text { strategy }\end{array}$ & Resources & $\begin{array}{l}\text { Mode } \\
\text { interaction }\end{array}$ & Employee participation & $\begin{array}{l}\text { Organisational } \\
\text { effects union }\end{array}$ \\
\hline Power Train & $\begin{array}{l}\text { Crisis, } \\
\text { Dismissals }\end{array}$ & $\begin{array}{l}\text { Challenge, } \\
\text { Promotion, } \\
\text { Controlling }\end{array}$ & $\begin{array}{l}\text { Consultancy, } \\
\text { Training }\end{array}$ & Dancing & Information, Proposals & None \\
\hline Miner & $\begin{array}{l}\text { Modernization } \\
\text { Plan } \\
\text { Management }\end{array}$ & $\begin{array}{l}\text { Companion, } \\
\text { Controlling }\end{array}$ & $\begin{array}{l}\text { Industry } \\
\text { Network } \\
\text { W.C. }\end{array}$ & $\begin{array}{l}\text { Dancing led by } \\
\text { Management }\end{array}$ & Information & None \\
\hline Sealer & $\begin{array}{l}\text { Relocation, } \\
\text { Dismissals }\end{array}$ & Plan & Consultancy & Local Dancing & Workshops, Assemblies & $\begin{array}{l}\text { Some Entries } \\
\text { (Derogation) }\end{array}$ \\
\hline Electro-nics & $\begin{array}{l}\text { Crisis, } \\
\text { Outsourcing, } \\
\text { Dismissals }\end{array}$ & Challenge & $\begin{array}{l}\text { Consultancy, } \\
\text { Training }\end{array}$ & Dancing Episode & Experts (selective) & None \\
\hline Energy & $\begin{array}{l}\text { Outsourcing, } \\
\text { Dismissals }\end{array}$ & $\begin{array}{l}\text { Plan, } \\
\text { Controlling }\end{array}$ & $\begin{array}{l}\text { Consultancy, } \\
\text { Training }\end{array}$ & Boxing & $\begin{array}{l}\text { Experts (selective), } \\
\text { Mobilization Conflict }\end{array}$ & $\begin{array}{l}\text { Reputation Blue } \\
\text { Collars }\end{array}$ \\
\hline Gear & $\begin{array}{l}\text { Outsourcing, } \\
\text { Concessions }\end{array}$ & $\begin{array}{l}\text { Plan, } \\
\text { Promotion }\end{array}$ & Training & Dancing & Information & None \\
\hline Cooler & $\begin{array}{l}\text { Crisis, } \\
\text { Pressure } \\
\text { Value Chain }\end{array}$ & $\begin{array}{l}\text { Challenge, } \\
\text { Companion, } \\
\text { Controlling }\end{array}$ & Consultancy & Boxing & Workshops, Surveys & $\begin{array}{l}\text { Some Entries } \\
\text { (Derogation) }\end{array}$ \\
\hline Shiner & $\begin{array}{l}\text { Joint } \\
\text { Modernization } \\
\text { Plan }\end{array}$ & $\begin{array}{l}\text { Plan, } \\
\text { Promotion }\end{array}$ & Consultancy & Dancing & Workshops, Surveys & $\begin{array}{l}\text { Some Entries } \\
\text { (Derogation) }\end{array}$ \\
\hline Motor & $\begin{array}{l}\text { Relocation, } \\
\text { Dismissals, } \\
\text { Concessions }\end{array}$ & $\begin{array}{l}\text { Plan, } \\
\text { Controlling }\end{array}$ & $\begin{array}{l}\text { Activation } \\
\text { Resources }\end{array}$ & Boxing Episode & Experts (selective) & $\begin{array}{l}\text { Reputation Blue } \\
\text { Collars }\end{array}$ \\
\hline Truck & $\begin{array}{l}\text { Relocation, } \\
\text { Dismissals, } \\
\text { Crisis }\end{array}$ & $\begin{array}{l}\text { Plan, } \\
\text { Promotion }\end{array}$ & $\begin{array}{l}\text { Consultancy; } \\
\text { Activation } \\
\text { Resources }\end{array}$ & Dancing & $\begin{array}{l}\text { Experts (selective and } \\
\text { not selective) }\end{array}$ & $\begin{array}{l}\text { Density White } \\
\text { Collars } 15 \text { to } 85 \% \\
\text { (with Derogation) }\end{array}$ \\
\hline Plow & $\begin{array}{l}\text { Outsourcing, } \\
\text { Concessions }\end{array}$ & $\begin{array}{l}\text { Plan, } \\
\text { Promotion }\end{array}$ & $\begin{array}{l}\text { Activation } \\
\text { Resources }\end{array}$ & Dancing & Experts and Survey & Some Entries \\
\hline Switcher & $\begin{array}{l}\text { Restructuring } \\
\text { Company }\end{array}$ & $\begin{array}{l}\text { Challenge, } \\
\text { Companion }\end{array}$ & Consultancy & Dancing & Information & $\begin{array}{l}\text { Some Entries } \\
\text { (Derogation) }\end{array}$ \\
\hline Closer & $\begin{array}{l}\text { Crisis, } \\
\text { Relocation, } \\
\text { Concessions }\end{array}$ & Companion & No changes & $\begin{array}{l}\text { Dancing led by } \\
\text { Management }\end{array}$ & Information & None \\
\hline Steel & $\begin{array}{l}\text { Dismissals, } \\
\text { Concessions }\end{array}$ & $\begin{array}{l}\text { Challenge, } \\
\text { Companion }\end{array}$ & Consultancy & Boxing & Experts & None \\
\hline Cement & $\begin{array}{l}\text { Outsourcing, } \\
\text { Dismissals }\end{array}$ & $\begin{array}{l}\text { Plan, } \\
\text { Controlling }\end{array}$ & $\begin{array}{l}\text { Consultancy, } \\
\text { Training }\end{array}$ & Boxing & $\begin{array}{l}\text { Experts, Mobilization } \\
\text { Conflict }\end{array}$ & $\begin{array}{l}\text { White Collars } \\
\text { above } 40 \%\end{array}$ \\
\hline Supplier & $\begin{array}{l}\text { Crisis, } \\
\text { Outsourcing }\end{array}$ & $\begin{array}{l}\text { Challenge, } \\
\text { Promotion, } \\
\text { Controlling }\end{array}$ & $\begin{array}{l}\text { Consultancy, } \\
\text { Training }\end{array}$ & Dancing & $\begin{array}{l}\text { Workshops, } \quad \text { Round } \\
\text { Tables, Experts }\end{array}$ & $\begin{array}{l}\text { White Collars } 5 \\
\text { to } 25 \% \\
\text { (Derogation) }\end{array}$ \\
\hline
\end{tabular}

First of all, the finding of the survey that "Better not Cheaper" strategies tend to be developed when works councils are on the defensive is confirmed by the results of the case study analysis. In all 16 cases except two (Miner and Shiner), management had threatened employment or labour standards or both by making moves to outsource or relocate production and by declaring a crisis situation. The term "crisis" here does not usually mean 
that companies, plants or departments were in the red but that they had not met expected rates of return. Globalization and financialization (in the sense that the interpretation schemes and norms of the financial market and financial measures are used as instruments by management [Froud, Johal, Leaver, \& Williams, 2006]) were being used by management to legitimise demands for downsizing, relocation or outsourcing of activities and, therefore, of employment. This occurred regardless of plant size or ownership structure.

How did the works councils react? The core and common denominator of the "better" strategies in our sample is the fact that management strategies were challenged by the works councils. Of course, challenging management is nothing really new for works councils. On the one hand, this is what works councils usually do in negotiations by pointing to negative social or employment effects. However, they rarely ask whether management strategies are actually likely to produce the economic results they promise or whether there are other strategies that might promise better results. On the other hand, there are individual cases in the metalworking industry where works councils have acted in line with the "better" practices analyzed here. Examples are the works councils of the large automotive plants, already mentioned above, which were confronted with relocation and outsourcing threats earlier than other works councils and were able to draw on material and personnel resources far superior to those of "normal" works councils in smaller plants. Other examples can be found in the context of policies for the improvement of regional structures; in some regions, innovation networks have developed, with IG Metall playing an important role in support of works councils seeking to develop innovative alternative plans (Dörre \& Röttger, 2006). However, what is common to these examples is that they remained isolated cases and did not address the problem of disorganized collective bargaining. The "Better not Cheaper" campaign is the first attempt to activate works councils systematically and across a whole bargaining region - and later on nationwide - as a response to the threats of disorganization described above.

However, challenging management strategies because of the economic effects they may have can be regarded as a new form of codetermination, since it is found systematically throughout the cases. The decisive point for works councils in challenging management strategies is whether or not they had developed alternative business plans. Some of the works councils we analyzed had alternatives, some had not. The decisive point is to use management's economic frame of reference in calling its strategies into question. In couching their challenges in these terms, the works councils make it impossible for management to ignore these questions or dismiss them as ideological. And this is what makes works councils strategic in the sense that they try to influence management decisions from the beginning in order not to be confronted with the employment or social consequences of decisions that can no longer be influenced.

An example of this practice is a company producing electronic household appliances (Electronics). Some years ago, management and the works councils agreed on a social compensation plan that includes the outsourcing of a component production unit. However, outsourcing proved to be difficult because no other reliable suppliers could be found. In this situation, the head of the works council attended a union workshop on outsourcing and was informed that he could get external consultancy if he wanted to. This marked a turning point for the works council, enabling him to call into question the agreement on outsourcing and to propose that the economic effects of alternative plans be examined. Management agreed to set up a work group composed of experts from different departments and led by academic consultants paid by the union. Finally, the expert group agreed on the economic superiority of in-house production for most of the components in question. Today, component production is an important element of a newly organized and rapidly expanding business unit.

In other cases in our sample works councils went a step further by developing alternative product strategies and negotiating them with management. One example is a company producing car engines (Motor). The works council was confronted with a management demand to derogate from the collective bargaining agreement by extending working times without pay compensation. It criticised management for having been too reluctant to invest and innovate. This, rather than labour costs, was the real problem the company was facing in the eyes of the works councils. As a consequence, the works councils at the company's German plants came together and tried to develop a common strategy for the company's future, drawing on analyses they had developed at their sites with the help of experts from different departments and different layers of management. The resulting plan, described as a "proactive production strategy", was subsequently the object of negotiations with the company. It was eventually agreed that the collectively agreed norms would be respected, that no dismissals would take place and that investments would be made to modernise products and production technologies.

What are the types of innovations dealt with in the case studies in the course of the "Better not cheaper" process? According to Kinkel, Lay and Wengel (2004) four types of innovation can be distinguished: product innovations, process innovations in the form of new production technologies, service innovations in the sense of new kinds of services accompanying the product and organizational innovations. Among the 48 initiatives of innovation in the 
case studies organizational innovations are dominating, ranging from new wage systems to de-centralization and process orientation of the organization, teamwork, continuous improvement and productivity programs up to extended co-management rights for the works councils (which can also be regarded as an organizational improvement because they give the works councils the legitimacy to codetermine issues of organizational change).
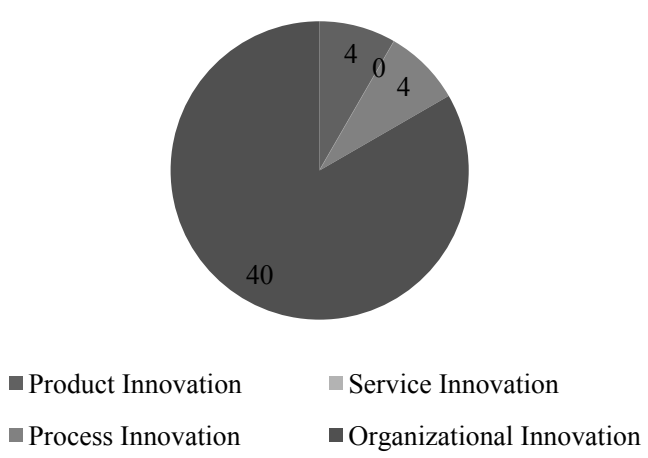

Figure 2. Number and types of innovation in the case studies

However it has to be said that the measures often have not defined coherent and encompassing business plans. In many cases, developing a "better" alternative to management strategies focused on improvements in work organization, either by enhancing the efficiency of a given organization or by implementing new forms of work organization based on teamwork. Strategies related to new products or business fields were rather rare. And in none of the cases works councils called into question the premises of management strategies regarding the financial targets of the companies which in many of the cases have been defined with implicit or explicit reference to the expectations of the financial markets. Challenging management strategies did not mean challenging financialization of companies.

\section{Competences for Strategic Codetermination and Patterns of Negotiation}

Challenging management strategies and, particularly, developing alternatives required the works councils to acquire or develop economic expertise. "You have to know how to interpret the data given by management if you want to counter their demand not to pay the Christmas bonus", one of the works councillors said. To adopt management's frame of reference means to be able to reconstruct and assess management's motives and strategies. "You have to understand the reasons why they do this and that. And this is the precondition for you to think about alternatives", another works councillor said. For developing alternatives, two more kinds of competence are of importance. The first is knowledge of the organization. Works councils have to know how the organization works if they want to confront management with alternative strategies for organizing work or the plant as a whole. Works councils normally have few problems in doing this because they usually know much better how the organization works than the managers, who change jobs frequently and in many cases leave a plant again before they can get an impression of how things are done. The second kind is strategic competency in market and business developments, of the sort required by the works councils of the automotive company that tried to develop strategies for products and markets the company should focus on.

How can the works councils acquire the competences they need? In our case studies the works councils developed three strategies. The first was to activate the competences they already had for solving a particular problem. This was what the works councils of Plough and Motor did. The second strategy was to attend seminars on special problems in order to acquire knowledge that could be activated in the works councils. This was the approach taken by Electronics' works council. The third strategy was to engage a union-oriented consultant. This was the dominant solution in our sample. Eleven of the 16 works councils we analyzed made use of the expertise of consultants, in most cases in combination with one of the other two strategies. However, the consultants were important in two respects: first, to interpret the data and figures presented by management and second, to develop alternative strategies together with the works councils and to show that in-house production could be as economically effective as outsourcing or off-shoring. At Trucks, for example, a consultant was present in the plant for ten full days, analyzing each department separately and holding workshops and discussions with employees. On the basis of the information thus gathered, he developed a new organizational scheme for the 
plant, building on integrated platforms of specialists rather than separate departments.

Consultancy was important for the works councils in another respect, namely in improving their power position vis-à-vis management. "The consultants helped us to be on a par with management" was a statement many works councillors made. Consultants were important in this respect for two reasons, first because of the high quality of alternatives the works councils were able to develop with the support of the consultancies, and second because of the high reputation the consultants have in the eyes of the management. In general it can be stated that strategic codetermination enhanced works councils' reputation with management. There is no case to be found in our sample where a works council was weaker at the end of the process than it had been at the beginning. This has a lot to do with the more active role the works councils are playing in labour relations because of strategic codetermination. To challenge management in its frame of reference also means to discover a new policy arena that used to be a management prerogative.

This new level of activity on the part of works councils is best described using the terminology of boxing and dancing presented by Huzzard (2004). Boxing and dancing can be interpreted as two different forms of strategic codetermination. Works councils that adopt a 'dancing' strategy are seeking to develop common projects with management based on trust relationships, while those that adopt a 'boxing' strategy are engaged with management in a fight for alternative strategies. In both strategies, works councils are actively seeking to shape management strategies, and in both cases a new consensus with management has to be achieved in order to be able to influence management strategies successfully. In our sample of cases, predominantly dancing strategies are more common than predominantly boxing strategies. In 10 of the 16 cases, works councils were 'dancing' with management. In two of these cases, Miner and Shiner, management was taking the lead on the dance floor. In these cases, the works councils agreed with management's goals and was simply trying to improve management strategies with respect to employees' working conditions. In the other cases, management and works councils jointly defined the direction the dancing was to take. In a plant producing foam sealing for cars (Sealer), dancing was a local phenomena. Here, management and works councils were forming a local coalition with the aim of saving the plant and to safeguarding jobs. The works council proposed innovations and tried to convince management of the value of the "Better not Cheaper" approach. It was the works councils who were the dominant partner on the dance floor, so to speak. In other cases, like the producer of gear components (Gear), the dancing stagnated. In this situation, management was kept on the dance floor by works council threats to swap the dance floor for the boxing ring. As the Gear works councillor said: "you have to show at least temporarily that you are willing to fight and that the employees are standing behind you, this is a precondition for talking together in a rational way." At a plant producing energy systems (Energy) the works council would have liked to dance, but could not find any willing partners on the management side. Several invitations to the dance were sent to management but no replies were received, mainly because of high management turnover. So counter-analysis and the development of alternative strategies were used by the works council to improve its position in the ring while negotiating agreements. One works councillor said: "I think it is important for countervailing power to go into business details, to defend what you have, yes, but also to do more than this."

The choice of strategies by the works councils depends mainly on the state of labor relations when the "Better not Cheaper" approach is first adopted. If management and works councils had previously reached agreement on their common interests and enshrined them in a social partnership, works councils tended to choose the dancing option. Conversely, if no feeling of commonalities and trust relationships existed previously, they usually opted for the boxing strategy. In two cases (Electronics and Tucks), dancing options were chosen by the works councils, despite being unable to build on relations of trust and social partnership; in these cases, the dancing was a mere interlude, without any lasting impact. Thus labour relations in the firms in our sample did not undergo any permanent changes. However, what did happen in most cases was that the existing systems of labour relations were activated in the "better"-process because the works councils started to play a more active or rather strategic - role and management had to react to this.

\section{Representation and Participation}

Changes induced by the "Better not Cheaper" campaign were not limited to works councils' codetermination strategies and labour relations but can also be observed in the relationship between works councils and employees. Rank-and-file participation is what has to be analysed here. As mentioned above, works councils have traditionally been intermediate actors, developing strategies and negotiating with management in a representative way, defining strategies for employees and not with them and negotiating with management behind closed doors as representatives of a common employee interest. This was also the usual way of dealing with participatory forms of work organization, such as semi-autonomous teamwork, in the 1980s and early 1990s, when companies were experimenting with new production systems (Schumann, Baethge-Kinsky, 
Kuhlmann, Kurz, \& Neumann, 1994) and works councils became co-managers. Works councils launched pilot projects with management without making much effort to take account of employees' interests or experience.

This style of interest management by works councils reaches its limits in processes linked to the 'Better not Cheaper' campaign. The main reason is that works councils and consultants became aware that the participation of employees, as experts in work and organization, was indispensable for challenging management strategies and developing alternative strategies. This is why in many of our cases works councils and consultants - and mostly the consultants had the more active part in doing this - developed new forms of professional employee participation. Employees as experts participated in two ways, by taking part either in surveys of larger groups of employees focusing on several problems or in smaller groups of employees, selected for their expertise, that were set up to provide a detailed solution to a particular problem. Selective participation was usually organized as a series of workshops, as at the producer of foam sealing (Sealer). Here the members of the works council, the consultant, construction engineers, a technician, an account manager and a worker tried to uncover potential for rationalization in a certain production area that was designated for outsourcing by management. The workshop was rather successful. Within a few hours the group was able to devise a plan for increasing productivity in a way not believed by management in advance. In the end, the area was not outsourced as management had planned. The consultant said that "we, the consultants, cannot perform magic - but the employees can. The employees know a lot of things, in most cases they do not really know what they know and what they are able to do. This was a very good case for showing what potential the works councils are able to develop together with the employees."

Moreover, works councils and consultants who have developed new modes of rank-and-file participation felt they enjoyed a considerable level of legitimacy among employees. This finding is confirmed by a contrasting case in our sample, where the works council remained a representative actor in the intermediary sense. Thus, at Plough a new continuous shift system was agreed between management and works council that had been developed without employee participation and was not liked by the employees. In the end, a lack of participation led to criticism and a loss of legitimacy for the works council.

\section{0. "Better Not Cheaper" and Union Revitalization}

Works councils are strengthened in the course of the "Better not Cheaper" campaign by developing proactive forms of codetermination, challenging management on its own terms and mobilising support from consultants and, especially, employees via rank-and-file participation. But what about the union? Has the revitalization of works councils also paved the way for a process of union renewal at the IG Metall? And how are both developments linked?

There is no simple answer to this question. First of all, it is important to distinguish between two dimensions of the "Better not Cheaper" campaign that correspond to two different forms of employee participation. One dimension of the campaign, the "fight against cheaper", is the dimension that is dominant in disputes concerning derogations. As explained above, participation by union members in negotiations on derogations has become the norm in IG Metall today. Members can vote at meetings on whether negotiations should take place or if an agreement should be accepted or not; they can also vote on the composition of collective bargaining committees (and can also sit on such committees). The second dimension of the "Better not Cheaper" campaign is what might be called the "fight for better". This fight usually goes hand in hand with employee participation in challenging management and developing alternative strategies. Here employees are participating as experts in work and organization. Of course the two forms of participation often go hand in hand. Thus, in the case of a producer of energy systems (Energy), the works council was able to prevent the outsourcing of a department by presenting a counter-strategy, in which it was able to demonstrate the strategic relevance of the department for the plant; and the counter-strategy was developed by experts from different departments, a consultant and the works council itself. Based on the counter strategy the works council was also able to mobilise the predominantly white-collar employees for a labour dispute and to make the union more attractive to employees.

However, it makes sense to distinguish between the two forms of participation analytically, because in other cases the relation between them is less direct and because both forms of participation have rather different effects on union renewal. What can be said for certain is that rank-and-file participation is the crucial factor for union renewal in the "Better not Cheaper" campaign. However, the effects differ depending on the form of participation. Participation based on the 'fight against cheaper' has proved to be much more effective for the union, at least in the short run. In most of the cases where the union was able to increase its membership base, new members joined the union in the course of negotiations on derogations (Haipeter, 2011b).

An impressive example of membership recruitment in the course of a 'fight against cheaper' is the case of an 
automotive component supplier (Supplier). Management wanted to negotiate derogations from the collective agreement for the administration centre, which is organized as an affiliated company. At the first employee meeting on the matter, the responsible union official told the employees that he would not negotiate an agreement for a company with a union density of 5\%; only 50 of the approximately 1,000 employees were union members at that time. Both this announcement and the prospect of taking part in the negotiations on the derogation encouraged 200 employees to become union members. Union density increased to about $25 \%$ in the course of the dispute.

The 'fight for better' does not offer similar membership gains. Here a strengthening of the union as a result of rank-and-file participation takes place - if at all - much more indirectly and over the long term. A precondition for positive organizing effects is that the works councils stress the role of the union in the development of "better" strategies. Thus, "better not cheaper" has to be combined with a membership campaign. In the case of the producer of household appliances (Electronics) where participation took the form of a workshop for employee experts whose objective was to reassess the outsourcing decision made in the social plan, the works council did not draw an explicit line between these activities and the union (although in this case the consultancy by academic experts was financed by the union), and in the end no effects on the organizational power of the union could be observed. On the contrary, in the case of the producer of energy systems (Energy), the works council underlined the role of IG Metall and tried to mobilise the workers for labour disputes by saying that this was an industrial action organized by IG Metall. In the course of the mobilization some of the non-organized employees joined the union - although the union density was already fairly high, with more than $80 \%$ of the blue-collar and more than $40 \%$ of the white-collar employees unionised.

To sum up, the 'fight for better' did not produce significant density effects. However, this does not mean that the 'fight for better' cannot contribute to the renewal of union power in the plants. Two points are important in this respect. The first point is that rank-and-file participation by workers as experts has to be be combined with a membership campaign, with campaign leaders making it clear that the development of "better" strategies is based on the union's support and the initiative and that the implementation of alternative strategies depends on the union's organizational power in the plant. If the union is weak, management has little incentive to negotiate with the works council, because its strength is also based to a large extent on union power.

The second point is that participation in "better" strategies can pave the way for new membership groups, especially white-collar employees. The precondition is that the works councils make the offer to participate as experts in the 'fight for better' not only to their traditional constituency of skilled blue-collar workers but also to white-collar workers, who have been so difficult to organize for the union up to now. Energy (which is a white-collar plant mainly) and Trucks are the two examples in our sample where works councils tried to do this, and in both cases union density among the white-collar workers was increased. 'Fighting for better' gives white-collar employees a chance to bring their expert knowledge, whether it be technical or commercial, to bear on the development of alternative strategies for workers in their struggle with management. In this way, collectivist attitudes and awareness of common interests with other workers can be strengthened in a group of employees that has usually be regarded as being interested more in the success of the company and in individual careers than in the support of unions or works councils (and rather the latter than the former, already in Kudera, Ruff, \& Schmidt, 1983; Weber-Menges, 2004). In this respect, union membership could be a final step in a process of reorientation that starts with being asked to provide expertise by a works council fighting for "better" strategies but without it being necessary to deny being a union member.

\section{Concluding Remarks}

Looking at the "Better not Cheaper" campaign and its significance for the development of codetermination, union revitalization and business strategies, six concluding remarks can be made. First, the campaign was rather effective in diffusing a practice of strategic codetermination among works councils that had existed previously only in some large automotive plants. The campaign succeeded in attracting works councils from the "normal world" of codetermination in plant sizes of between 200 and 2000 employees. It was precisely in these plants that works councils were increasingly being pressed by management to make concessions and increasingly being made aware that globalization and financialization had increased management's room for manoeuvre at their expense by downsizing, relocation or outsourcing of employment. The diffusion of the campaign was facilitated by the fact that the campaign slogan was memorable and left room for interpretation so that it could be used in various ways against the employers' offensive.

Second, works councils developed a new style of codetermination based on challenging management decisions in economic terms. By developing strategic codetermination, works councils are entering management's frame 
of reference and discovering a new arena of conflict. This form of codetermination can be labelled "strategic" because it is focused on management strategies and the development of strategic alternatives. On the one hand, it builds on more traditional forms of codetermination in its political focus on the safeguarding of jobs and preservation of the labour standards set out in collective agreements. On the other hand, it is new in the sense that it represents for the first time a systematic attempt by works councils to move away from coping with the social effects of management decisions, such as relocation and outsourcing, in favour of influencing management decisions and developing alternatives that, in economic and business terms, are as good as or superior to management's proposals. However, neither the 'boxing' nor the 'dancing' approach to challenging management calls social partnership into question. Rather, it represents an activation of social partnership in the sense that the social partners are becoming more active and that management strategy is becoming a new arena for interaction and negotiation - or politics - based on social partnership.

Third, strategic codetermination requires works councils to acquire or develop economic, organizational and strategic competences, which they have demonstrated they are able to do. They have reorganized their committees, coordinated and taken part in further training measures on topics such as globalization or innovation strategies and, perhaps most importantly of all, organized support from external consultants who have helped them to assess management plans and proposals and to develop alternatives. The activation of competences is another important element of strategic codetermination, because the works councils have started to deal with their resources in a strategic manner.

The activation of competences, and this is the fourth point to stress, depends largely on the union and the service structure the union put in place in the course of the campaign. Works councils obtained valuable inputs from the seminars the union organized during the campaign on issues such as globalisation, new production systems or innovation strategies. Furthermore, the union organized a network of union-oriented consultants on whom the works councils could call, availing themselves of financial support from the union if needed (in some cases the employers were liable under the terms of the WCA to pay for the consultants). The lessons learnt in the course of the campaign can be regarded as further proof of Behrens' hypothesis that, in the German institutional context, the service model is vitally important for the unions and their revitalization. However, the campaign not only built on traditional forms of union support but also created new ones, such as seminars on topics chosen by the works councils themselves, the establishment of networks of consultants, etc.

Fifth, strategic codetermination goes hand in hand with a new relationship between works councils and employees. In the context of the "Better not Cheaper" campaign, works councils started to call on employees' expertise in order to develop alternative to management strategies. A close relationship with the workforce is the works councils' main advantage in the competition of business strategies. By exploiting that relationship, the works councils were able to improve their power position in labour relations. Failure to make use of this advantage could well endanger their position, since they would be running the risk of promoting innovations that do not reflect the interests of the workforce. Expert participation signals a fundamental change in dealing with employees' interests by works councils and unions. Unlike the traditional form of intermediate collective action, strategies are no longer defined from above, and negotiations no longer take place behind closed doors (Weitbrecht, 1969). Rank-and-file participation has enabled the works councils to develop alternatives to management strategies and to strengthen their legitimacy and their organizational power.

Sixth, the activation of works councils can be regarded as an important element of union revitalization because the more active and effective works councils are, the more attractive they are to employees and the stronger they are in disputes with management about relocation or outsourcing. However, regarding union revitalization in the sense of membership recruitment the campaign has been proven to be much less successful. Thus the positive expectations formulated in the literature are not fully borne out by the empirical evidence. The campaign is contributing to union revitalization by strengthening the works councils, not by attracting members, and it makes sense to distinguish at least between these two indicators of revitalization. So the union should convince the works councils to put more emphasis on membership campaigns and to combine them with the fight for new business concepts. However, by treating employees as experts in work and organization, new linkages can be established between the union and groups of workers, such as white-collar employees, who have not traditionally been very union-oriented.

Finally, in many cases the "better" alternatives and solutions have been a good deal away from coherent business plans. They were focusing on improvements in work organization, either by enhancing the efficiency of a given organization or by implementing new forms of work organization based on teamwork. And in this respect the new solutions and measures have proven to be economically superior, mainly because rank-and-file participation was organized more effectively than management would have been able to do it. However, strategies related to 
new products or business fields were rather rare. And in none of the cases analyzed here works councils called into question the premises of business strategies regarding the financial orientations of management. It seems to be an open question whether such a piecemeal approach will be enough to put into practice the idea of innovative quality production based on qualification and participation of employees which is forming the intellectual core of the "Better not cheaper" campaign. There are good reasons to argue that it will be difficult to activate and to innovate the production model of coordinated capitalism under the conditions of financialized capitalism, and that long term "better" strategies also would require long term financial orientations of management. However, the fact that this aspect of "better" strategies has not taken up yet by the works councils does not mean that it will not be taken up in the future. The experiences made in the campaign suggest that it will depend largely on the union's strategy whether this will happen or not.

\section{References}

Baccaro, L., Hamann, K., \& Turner, L. (2003). The Politics of Labor Movement Revitalization: The Need for a Revitalized Perspective. European Journal of Industrial Relations, 9(1), 119-113. http://dx.doi.org/10.1177/0959680103009001455

Behrens, M. (2009). Still Married after all these years? Union Organizing and the Role of Works Councils in German Industrial Relations. Industrial and Labor Relations Review, 62(3), 275-293.

Bergmann, J. (2001). Betriebsräte im Shareholder-Kapitalismus: ratlos. Einige Befunde aus einer Befragung von Betriebsräten und Vertrauensleuten. In J. Abel, \& H. Sperling (Eds.), Umbrüche und Kontinuitäten. Perspektiven nationaler und internationaler Arbeitsbeziehungen (pp. 101-112). München/Mering: Hampp.

Bosch, G., Haipeter, T., Latniak, E., \& Lehndorff, S. (2007). Demontage oder Revitalisierung? Das deutsche Beschäftigungsmodell im Umbruch. Kölner Zeitschrift für Soziologie und Sozialpsychologie, 59(4), 318-339. http://dx.doi.org/10.1007/s11577-007-0031-0

Bronfenbrenner, K., Friedman, S., Hurd, R. W., Oswald, R. A., \& Seeber, R. L. (Eds.). (1998). Organizing to Win. New Research on Union Strategies. Ithaca, New York: Cornell University Press.

Doellgast, V., \& Greer, I. (2007). Vertical Desintegration and the Disorganization of German Industrial $\begin{array}{llll}\text { Relations. British Journal of Industrial Relation, 45(1), 55-76. } & \text {. }\end{array}$ http://dx.doi.org/10.1111/j.1467-8543.2007.00602.x

Dörre, K., \& Brinkmann, U. (2005). Finanzmarktkapitalismus - Triebkraft eines flexiblen Produktionsmodells? In P. Windolf (Ed.), Finanzmarktkapitalismus. Analysen zum Wandel von Produktionsregimen (pp. 85-116). Wiesbaden: Westddeutscher Verlag.

Dörre, K., \& Röttger, B. (2006). Im Schatten der Globalisierung. Strukturpolitik, Netzwerke und Gewerkschaften in altindustriellen Regionen. Wiesbaden: VS Verlag für Sozialwissenschaften. http://dx.doi.org/10.1007/978-3-531-90360-6

Frege, C., \& Kelly, J. (2004). Union Strategies in a Comparative Context. In C. Frege, \& J. Kelly (Eds.), Varieties of Unionism: Strategies for Union Revitalization in a Gloabilizing Economy (pp. 31-44). Oxford: University Press.

Froud, J., Johal, S., Leaver, A., \& Williams, K. (2006). Financialization and Strategy. Narrative and Numbers. London: Routledge.

Haipeter, T. (2006). Recent developments in co-determination at Volkswagen: challenges and changes. Journal of Industrial Relations, 48(4), 541-546. http://dx.doi.org/10.1177/0022185606066144

Haipeter, T. (2009). Tarifabweichungen und Flächentarifverträge: Eine Analyse der Regulierungspraxis in der Metall- und Elektroindustrie. Wiesbaden: VS Verlag für Sozialwissenschaften.

Haipeter, T. (2011a). 'Unbound' Employers' Associations and Derogations - Erosion and Renewal of Collective Bargaining in the German Metalworking Industry. Industrial Relations Journal, 42(2), 174-194. http://dx.doi.org/10.1111/j.1468-2338.2011.00615.x

Haipeter, T. (2011b). Works Councils as Actors in Collective Bargaining. Derogations and the Development of Codetermination in the German Chemical and Metalworking Industries. Economic and Industrial Democracy, 32(4), 679-695. http://dx.doi.org/10.1177/0143831X10393039

Hall, P. A., \& Soskice, D. (2001). Introduction. In Hall, P. A., \& Soskice, D. (Eds.), Varieties of capitalism: the institutional foundations of comparative advantage (pp. 1-71). Oxford: University Press.

Hassel, A. (1998). The Erosion of the German System of Industrial Relations. British Journal of Industrial 
Relations, 37(3), 483-505. http://dx.doi.org/10.1111/1467-8543.00138

Hickey, R., Kuruvilla, S., \& Lakhani, T. (2010). No Panacea for Success: Activism, Organizing and Union Renewal. British Journal of Industrial Relations, 48(1), 53-83. http://dx.doi.org/10.1111/j.1467-8543.2009.00743.x

Huzzard, T. (2004). Boxing and Dancing - Trade Union Strategic Choices. In T. Huzzard, D. Gregory, \& R. Scott (Eds.), Strategic Unionism and Partnership. Boxing or Dancing? (pp. 20-44). Houndmills, Basingstoke: Palgrave.

Kädtler, J. (2009). Tarifautonomie und Sozialpartnerschaft - Ein Kommentar. Beitrag zum Symposium "60 Jahre Tarifvertragsgesetz - Zukunft der Tarifautonomie", 23./24.04.2009 in Berlin.

Kinkel, S., Lay, G., \& Wengel, J. (2004). Innovation: Mehr als Forschung und Entwicklung. Wachstumschancen auf anderen Innovationspfaden. Fraunhofer Institut Systemtechnik und Innovationsforschung: Mitteilungen aus der Produktionsinnovationserhebung, 33.

Kotthoff, H. (1994). Betriebsräte und Bürgerstatus. Wandel und Kontinuität der Mitbestimmung. München/Mering: Hampp.

Kotthoff, H. (1995). Betriebsräte und betriebliche Reorganisation. Zur Modernisierung eines 'alten Hasen'. Arbeit, 4(4), 425-447.

Kotthoff, H. (1998). Mitbestimmung in Zeiten interessenpolitischer Rückschritte. Betriebsräte zwischen Beteiligungsofferten und "gnadenlosem Kostensenkungsdiktat". Industrielle Beziehungen, 5(1), 76-100.

Kudera, W., Ruff, K., \& Schmidt, R. (1983). Blue Collar - White Collar: Grey Collar? Zum sozialen Habitus von Arbeitern und Angestellten in der Industrie. Soziale Welt, 34(2), 201-227.

Lehndorff, S., \& Haipeter, T. (2011). Negotiating Employment Security: Innovations and Derogations. In S. Hayter (Ed.), The Role of Collective Bargaining in the Global Economy: Negotiating for Social Justice (pp. 20-46). Cheltenham: Elgar.

Müller-Jentsch, W. (1985). Trade Unions as Intermediary Organizations. Economic and Industrial Democracy, 6(1), 3-33. http://dx.doi.org/10.1177/0143831X8561002

Müller-Jentsch, W. (1995). Germany, 'From Collective Voice to Co-Management'. In J. Roger, \& W. Streeck (Eds.), Works Councils. Consultation, Representation and Cooperation in Industrial Relations (pp. 53-78). Chicago/London: The University of Chicago Press.

Müller-Jentsch, W. (2010). Vom Klassenkampf zum Korporatismus. Gewerkschaften im rheinischen Korporatismus a.D. Blätter für deutsche und internationale Politik, 7, 61-70.

Rehder, B. (2003). Betriebliche Bündnisse für Arbeit in Deutschland. Mitbestimmung und Flächentarif im Wandel. Frankfurt/New York: Campus Verlag.

Rehder, B. (2006). Legitimitätsdefizite des Co-Managements. Betriebliche Bündnisse für Arbeit als Konfliktfeld zwischen Arbeitnehmern und betrieblicher Interessenvertretung. Zeitschrift für Soziologie, 35(3), 227-242.

Schmidt, R., \& Trinczek, R. (1999). Der Betriebsrat als Akteur der industriellen Beziehungen. In W. Müller-Jentsch (Ed.), Konfliktpartnerschaft. Akteure und Institutionen der industriellen Beziehungen (pp. 103-129). München/Mering: Hampp.

Schumann, M., Baethge-Kinsky, V., Kuhlmann, M., Kurz, C., \& Neumann, U. (1994). Trendreport Rationalisierung. Automobilindustrie, Werkzeugmaschinenbau, Chemische Industrie. Berlin: Edition Sigma.

Streeck, W. (1979). Gewerkschaftsorganisation und industrielle Beziehungen. Politische Vierteljahresschrift, 20(3), 241-257.

Streeck, W., \& Schmitter, P. C. (1984). Community, Market, State - and Associations? The Prospective Contribution of Interest Government on Social Order. In W. Streeck \& P.C. Schmitter (Eds.), Private Interest Government. Beyond Market and State (pp. 1-29). London, Beverly Hills, New Delhi: Sage.

Thelen, K. (2009). Institutional Change in Advanced Political Economies. British Journal of Industrial Relations, 47(3), 471-498. http://dx.doi.org/10.1111/j.1467-8543.2009.00746.x

Traxler, F. (1995). Farewell to Labour Market Associations? Organized versus Disorganized Decentralization as a Map for Industrial Relations. In F. Traxler, \& C. Crouch (Eds.), Organized Industrial Relations in Europe: What Future? (pp. 3-21). Aldershot: Ashgate. 
Turner, L. (1998). Fighting for Partnership. Labor and Politics in Unified Germany. Ithaca, London: Cornell University Press.

Turner, L. (2008). Institutions and Activism: Crisis and Opportunity for a German Labor Movement in Decline. Industrial and Labor Relations Review, 62(3), 294-312.

Weber-Menges, S. (2004). Arbeiterklasse oder Arbeitnehmer? Vergleichende empirische Untersuchung zu Soziallage, Lebenschancen und Lebensstilen von Arbeitern und Angestellten in Industriebetrieben. Wiesbaden: VS Verlag für Sozialwissenschaften.

Weitbrecht, H. (1969). Effektivität und Legitimität der Tarifautonomie. Eine soziologische Untersuchung am Beispiel der deutschen Metallindustrie. Berlin: Duncker und Humblot. 